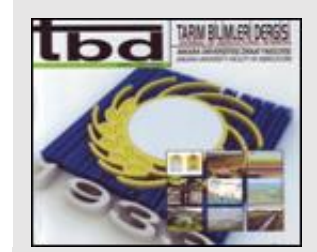

Tarım Bilimleri Dergisi Tar. Bil. Der.

Dergi web sayfası: www.agri.ankara.edu.tr/dergi
Journal of Agricultural Sciences

Journal homepage:

www.agri.ankara.edu.tr/journal

\title{
A New Pest Species Delia platura Meigen, (Diptera: Anthomyiidae) on Garlic (Allium sativum L., Alliaceae) Area in Kastamonu Province of Turkey
}

\author{
Pervin ERDOGAN ${ }^{a}$ \\ ${ }^{a}$ Sivas University of Science and Technology, Faculty of Agricultural Sciences and Technology Plant Protection Department, Sivas, TURKEY
}

\author{
ARTICLE INFO \\ Research Article \\ Corresponding Author: Pervin ERDOGAN, E-mail: pervinerdogan @ sivas.edu.tr , Tel: +90 (533) 6624650 \\ Received: 10 January 2019, Received in Revised Form: 08 March 2019, Accepted: 04 April 2019
}

\section{AUTHORS ORCID ID:}

(Pervin ERDOGAN: 0000-0001-5553-4876)

\section{ABSTRACT}

Garlic (Allium sativum L., Alliaceae) is consumed at all stages from fresh to dry in Turkey. Major harmful factors, pests for example, bring about a significant loss in garlic production. Studies carried out in Kastamonu garlic areas to determine the harmful pests revealed that the important harmful pest was Delia platura Meigen, (Diptera: Anthomyiidae) in the garlic fields. Population dynamics of $D$. platura was studied using yellow sticky traps in autumn and spring seasons of planting garlic fields. Plants were checked with trap controls and searched for $D$. platura on garlic plants. Plants tested were recorded
\end{abstract}

as infested and non-infested. The testing of traps finished in two weeks after the harvest. As a result, D. platura, the first emergence of the adult, was detected on March 21, 2017 in autumn planting and in spring planting. In the autumn planting, the highest number of adults caught in traps was on April 2015 with 4 adult/trap/week. In spring planting, the first adult in the trap was 1 adult/trap/week on 14 March, 2015. The study conducted in 2017, the first time of adult determination on trap was on March 18, 2017 in autumn planting. In spring planting, the first adult emerged on March 18, 2017.

Keywords: Seecorn maggots; Population dynamic; Garlic

(C) Ankara Üniversitesi Ziraat Fakültesi

\section{Introduction}

Garlic, Allium sativum (L.) (Alliaceae) consisting of sucrose, glucose, A, B and C vitamins, alliin, allicin, ajoen essential oils is an important food for people nutrition. The usage of garlic is believed to protect heart disease, cancer, and infection. The health benefits of garlic is also claimed to be lowering blood pressure and cholesterol, an protecting inflammatory reducing the risk of cancer, and a strengthening immune system (Anonymous 2018a).

There are 500 species of Allium genus in the world. Approximately 150 species of Allium genus, 57 of which fall into the group of fragrant garlic in the head or bulbs. The most important species of garlic is Allium sativum, which have become an important commercial product in Turkey and both fresh and dried garlic is produced in Turkey. According to the latest data, the production of fresh garlic is 25.519 tons, and dried garlic is 117.688 tons (Anonymous 2018b).

Many pests such as Delia antiqua Meigen (Diptera:Anthomyiidae), Delia platura Meigen (Diptera:Anthomyiidae), Thrips tabaci L. (Thysanoptera:Thripidae), Frankliniella occidentalis (Pergande) (Thysanoptera:Thripidae), Rhyzoglyphus spp., (Acari:Acaridae), Tyrophagus spp. (Acari:Acaridae), Aceria tulipae (Keifer) (Acari:Eriophyoidea) reduce the production of garlic (Anonymous 2016). Previous studies carried out in Turkey reported garlic pests as Bactericera tremblayi Wagner (Hemiptera: Psylloidea), T. tabaci, F. occidentalis (Thysanoptera:Thripidae), Acrolepiopsis assectella (Zeller) (Lepidoptera:Acrolepiidae), Agriotes spp. (Coleopteran:Elateridae), Liriomyza spp. 
(Diptera:Agromyzidae) and Ditylenchus dipsaci (Kühn) (Tylenchida:Anguinidae) in garlic cultivation areas (Anonymous 2008). However, in recent years, garlic producers have complained about side effects of the pest on garlic production. This pest has been become common and caused significant loss of garlic yield. Some producers have even maintained that they did not get any yields.

This study conducted in 2015 and 2017 years in Taşköprü-Kastamonu province, aimed at determining the pest in garlic production areas.

\section{Material and Methods}

\subsection{Pest determination studies}

Garlic plants were collected from garlic production areas during the production season. They were taken to laboratory for investigation. First larvae were determined and then they were fed to develop into adults and they were sent to experts for recognition. The adults were identified as Delia platura Meigen (Diptera:Anthomyiidae) by Hans Georg Rudzinski.

\subsection{Population monitoring studies}

Population monitoring methods were carried out by using yellow sticky traps (20x25 cm diameter) in autumn and spring garlic cultivation fields. During 2015, autumn planting was on September 15-18 and the spring planting was on March 10-15, 2016. Autumn planting for the year of 2017 was on September 18-25 and the spring planting was on March 5-10, 2016. Soon after the seedling emergence, yellow sticky traps were placed on a stake and placed $25 \mathrm{~cm}$ above the soil. When counting in traps plants were checked and searched for any larvae on garlic plants. Traps were replaced with every week. The plants were collected for 20/da and taken to laboratory. Then these plants were examined by stereo microscope and recorded as infested and non-infested. The counts of traps were completed within two weeks after harvesting (Erdoğan et al 2014). No insecticide was used in the study areas. Climate data of the study areas were obtained from the General Directorate of Meteorology (Anonymous 2017).

\section{Results and Discussion}

\subsection{Pest determination studies}

D. platura was recorded for the first time garlic fields in Turkey.

\subsection{Population dynamic of Delia platura}

In the autumn planting, the first adult emergence date was March 15, 2015. The highest number of adults was on March 29, 2015 with 4 adult/trap/week. The lowest number of adults was on April 19, 2015. The highest infestation rate was 7\% in the same field. In the spring planting, the first adult emergence date was April 5, 2015. On the same date, the rate of infestation was $4 \%$. The highest number of adults caught in the trap was 2 adult/trap/week. The highest infestation rate was $4 \%$ rate on the same field (Table 1). Studies in 2017, in the autumn planting, the date of first adult emergence was March 15, 2017. The highest number of adults was determined on May 5, 2017 (99 adult/trap/week). Peak activity was in May with approximately 99 adults per trap week. In the same field, the highest of rate infestation was $41 \%$. The plants were harvested on July 7, 2017 (Table 2). In the spring planting, as shown in Table 2, the date of the first emergence of adult was March 15, 2017. The highest number was 95 adult/trap/week on April 5, 2017. The highest infestation rate (36\%) was determined on April 26, 2017 in the same field (Table 2).

D. platura was first determined garlic fields in Turkey in this study. D. platura is the most widespread Anthomyiidae occurring all over the continents except Antarctica (Griffiths 1993). It was first reported in Germany and it is presently well established throughout the United States, including Alaska and Hawaii, and southern Canada (Gesell 2000). It is a major pest in North and South America as well as in Europe (Kornegay \& Cardona 1991) and is commonly found in Japan, India, Australia and New Zealand (Trotus et al 1996). D. platura is reported to be hosted by Allium species (Griffiths 1986; Howard et al 1994). The Seedcorn maggot is on the other hand a polyphagous pest, affecting more than 40 different host plants (Ristich 1950). It is an important pest germinating soybeans and corn (Funderburk et al 1983; Bessin 2004) and may infect a wide range of horticultural crops including beans, peas, cucumber, melon, onion, pepper, potato, and other vegetables (Kessing \& Mau 1991). In our country, the hosts of D. platura are vegetables such as bean, pumpkin, cucumber, melon and watermelon (Anonymous 2008). 
Table 1- Delia platura Meigen adult number (adult/trap/week) and infestation rates captured in traps in garlic field of Taşköprü/Kastamonu province) (2015)

\begin{tabular}{lcccc}
\hline \multirow{2}{*}{$\begin{array}{l}\text { The date of } \\
\text { counts }\end{array}$} & \multicolumn{2}{l}{ The autumn planting } & \multicolumn{3}{c}{ The spring planting } \\
\cline { 2 - 5 } & $\begin{array}{l}\text { The number of } \\
\text { adults/trap }\end{array}$ & $\begin{array}{c}\text { The rate of } \\
\text { Infestation } \\
(\%)\end{array}$ & $\begin{array}{c}\text { The number of } \\
\text { adults/trap }\end{array}$ & $\begin{array}{c}\text { The rate of } \\
\text { Infestation } \\
(\%)\end{array}$ \\
\hline $01.03 .2015^{*}$ & - & - & - & - \\
08.03 .2015 & 0 & 0 & 0 & 0 \\
15.03 .2015 & 2 & 0 & 2 & 4 \\
22.03 .2015 & 3 & 6 & 1 & 2 \\
29.03 .2015 & 4 & 7 & 0 & 0 \\
05.04 .2015 & 3 & 0 & 0 & 0 \\
12.04 .2015 & 2 & 0 & 0 & 0 \\
19.04 .2015 & 1 & 6 & 0 & 0 \\
26.04 .2015 & 0 & 1 & 0 & 0 \\
03.04 .2015 & 0 & 0 & 1 & 0 \\
10.05 .2015 & 0 & 0 & 0 & 0 \\
17.05 .2015 & 0 & 0 & 0 & 0 \\
24.05 .2015 & 0 & 0 & 0 & 0 \\
31.05 .2015 & 0 & 0 & 1 & 0 \\
07.05 .2015 & 0 & 0 & 0 & 0 \\
\hline
\end{tabular}

*, the date of trap placement

Table 2- Delia platura Meigen adult number (adult/trap/week) and infestation rates captured in traps in garlic field of Taşköprü/Kastamonu province) (2017)

\begin{tabular}{|c|c|c|c|c|}
\hline \multirow[b]{2}{*}{$\begin{array}{l}\text { The date of } \\
\text { counts }\end{array}$} & \multicolumn{2}{|c|}{ The autumn planting } & \multicolumn{2}{|c|}{ The spring planting } \\
\hline & $\begin{array}{l}\text { The number of } \\
\text { adults/trap }\end{array}$ & $\begin{array}{l}\text { The rate of } \\
\text { infestation } \\
(\%)\end{array}$ & $\begin{array}{l}\text { The number of } \\
\text { adults/trap }\end{array}$ & $\begin{array}{l}\text { The rate of } \\
\text { infestation } \\
\text { (\%) }\end{array}$ \\
\hline 01.03 .2017 & $*$ & $*$ & $*$ & $*$ \\
\hline 08.03.2017 & 0 & 0 & 0 & 0 \\
\hline 15.03 .2017 & 4 & 0 & 4 & 0 \\
\hline 22.03 .2017 & 18 & 3 & 42 & 9 \\
\hline 29.03 .2017 & 26 & 4 & 80 & 17 \\
\hline 05.04 .2017 & 33 & 7 & 95 & 22 \\
\hline 12.04 .2017 & 50 & 27 & 72 & 29 \\
\hline 19.04.2017 & 39 & 32 & 59 & 24 \\
\hline 26.04 .2017 & 23 & 24 & 37 & 36 \\
\hline 03.05 .2917 & 90 & 37 & 23 & 29 \\
\hline 10.05 .2017 & 99 & 41 & 25 & 25 \\
\hline 17.05.2017 & 74 & 36 & 15 & 22 \\
\hline 24.05 .2017 & 60 & 24 & 12 & 28 \\
\hline 31.05 .2017 & 22 & 19 & 11 & 24 \\
\hline 08.06 .2017 & 10 & 11 & 16 & 14 \\
\hline 15.06 .2017 & 11 & 7 & 14 & 9 \\
\hline 22.06 .2017 & 5 & 3 & 12 & 7 \\
\hline $30.06 .2017 * *$ & 3 & - & 6 & 4 \\
\hline 07.07.2017 & 2 & - & 6 & 3 \\
\hline $15.07 .2017 * * *$ & 3 & - & 4 & 3 \\
\hline 20.07.2017 & - & - & 8 & - \\
\hline 26.07.2017 & & & 5 & \\
\hline
\end{tabular}

*, the date of trap placement; **, the date of harvest in autumn planting; ***, the date of harvest in spring planting

In the present study, D. platura population dynamic was conducted on garlic field 2015 and 2017 years in TaşköprüKastamonu province. The yellow sticky traps were observed to be effective at catching D. platura, which was present 
from March to July. Our findings are consistent with those in the related literature. Ellis \& Scatcherd (2007) reported, the yellow sticky traps capturing the adults D. platura. In addition, Vernon et al (1987) noted that yellow was the most effective color attracting vegetable-infesting insects including D. platura. In addition, it was maintained that the yellow sticky traps were effective at catching D. platura (Robert et al 1987; Broatch \& Vernon 1997).

The population dynamic studies (2015) on D. platura, in this study the first emergence of the adult was detected in March in both the autumn planting and spring planting (Average temperature and humidity was $12{ }^{\circ} \mathrm{C}$ and $95 \%$ respectively), but short after then the population of $D$. platura suddenly stopped (Figure 1,2 ). We checked the trap on until May and finished counting at the end of May since there was no sign of adult D. platura. It might have been resulted from the heavy rainfall during the months of April and May (February: 0, March: 5, 9; April: 30, 8; May: 41, $3 \mathrm{~kg} \mathrm{~m}^{-2}$, Anonymous 2015) (Figure 3). Similarly Kansu (2005), reported that some insect species spending a certain biological period in the soil by the combination of rainfall and low temperature were adversely affected by population density. To the best our knowledge, there is no study on $D$. platura related to this issue though there are a few studies on different pests. Erdogan et al (2014) revealed that total precipitation had a negative effect on population density of pest. Similarly, it was noted that the density of potato moth population was inversely related to temperature and inversely related to rainfall (Von et al 1987). In addition, in the Central Anatolia Region, a decrease of rainfall on the days of the flight of the potato moth was recorded (Has et al 1996). It was determined that the heavy rainfall during the month of May in the Aegean region caused a decrease in the population of potato tuber moths (Zümreoğlu 1996). In addition, might be a noteworthy decrease in the potato moth populations during the rainy seasons as well as in the sprinkling in the fields (Raman et al 1987).

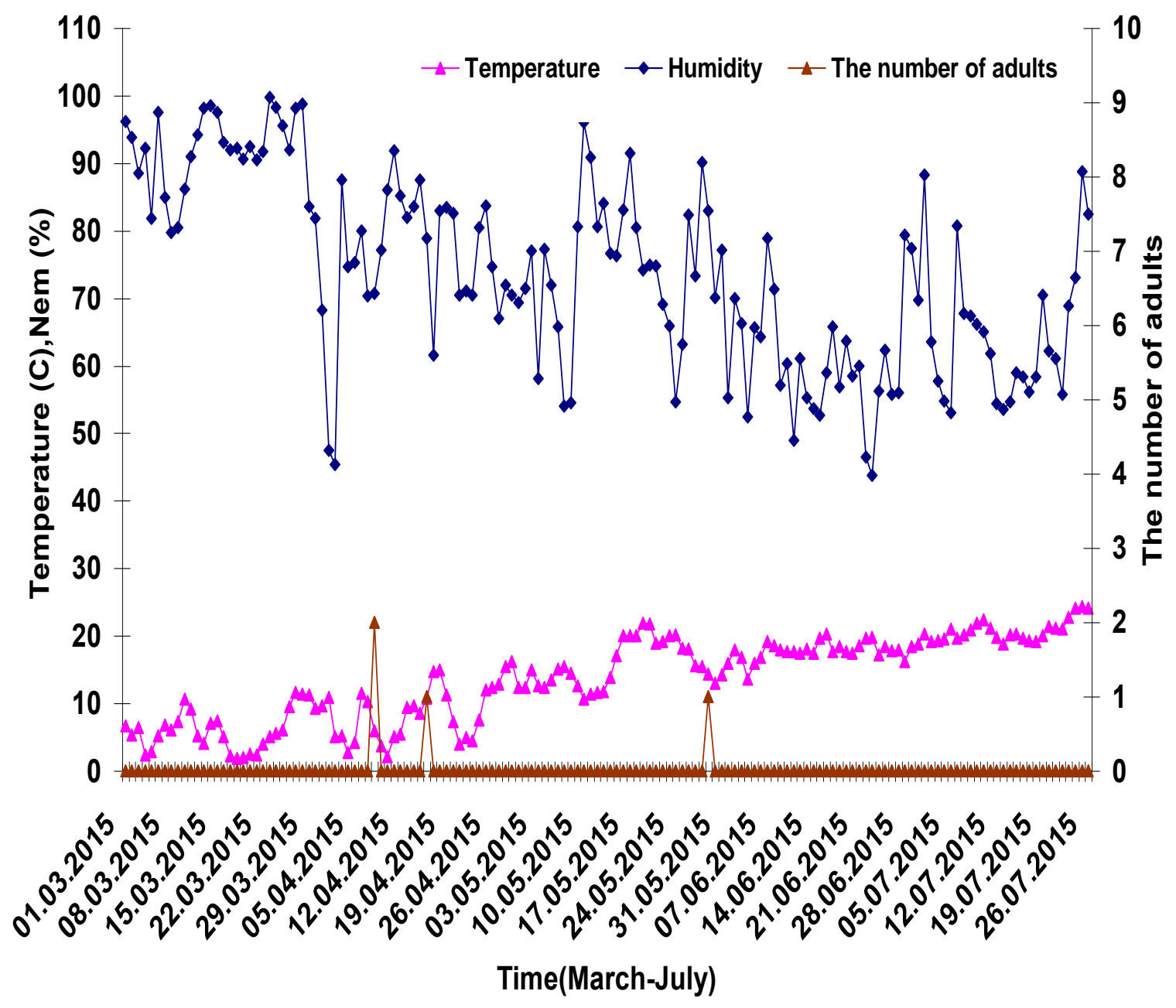

Figure 1- Temperature, humidity and the number of adults obtained from in the spring planting garlic 


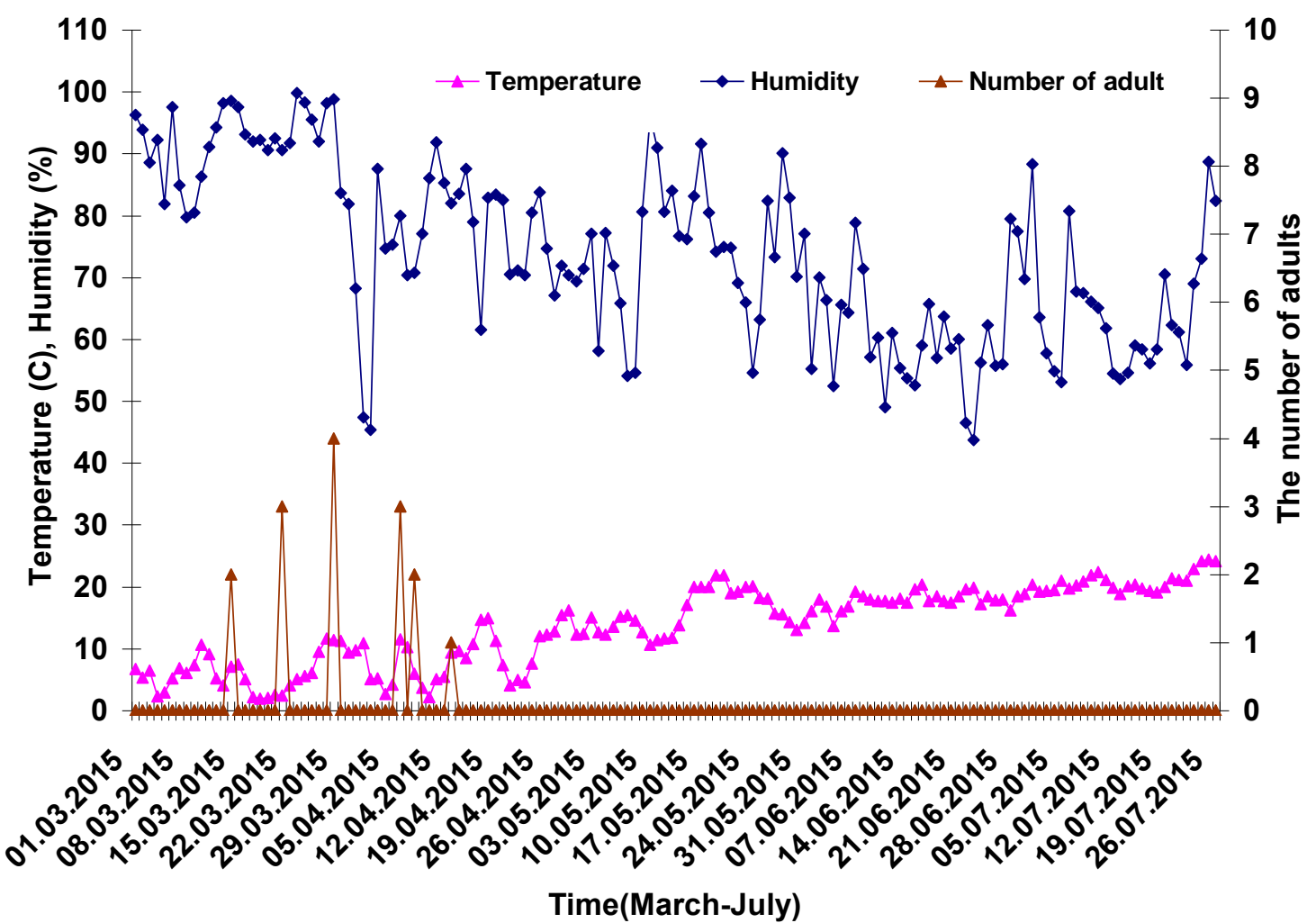

Figure 2-Temperature, humidity and the number of adults obtained from in the autumn planting garlic

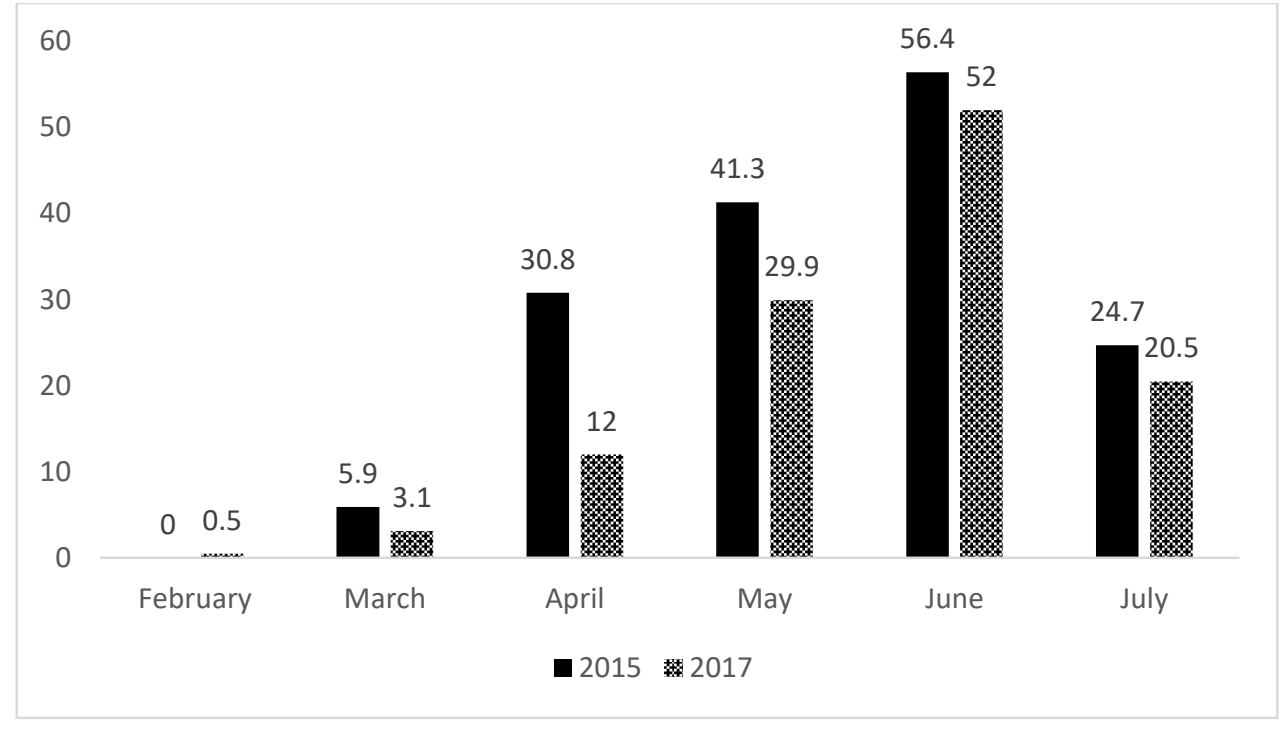

Figure 3- During the study of population dynamic determined total monthly precipitation $\left(\mathrm{kg} \mathrm{m}^{-2}\right)$

In the studies carried out in 2017, it was found that the first adult emerged on March both in the autumn planting and the spring planting (Average temperature and humidity $10^{\circ} \mathrm{C}$ and $65 \%$ respectively), and the adult population increased until the beginning of March, April and May and then it decreased. A total of 614 adults were trapped in the autumn planting with peak activity in May. In the spring planting, a substantial number of adults were observed in three peaks, yet only 546 adults of $D$. platura were trapped. The highest number of adults were determined as 99 adults /week/trap in the autumn planting on May 10, 2017 (Figure 4). The average temperature and humidity were recorded as $15^{\circ} \mathrm{C}$ and 85 $70 \%$, respectively. 


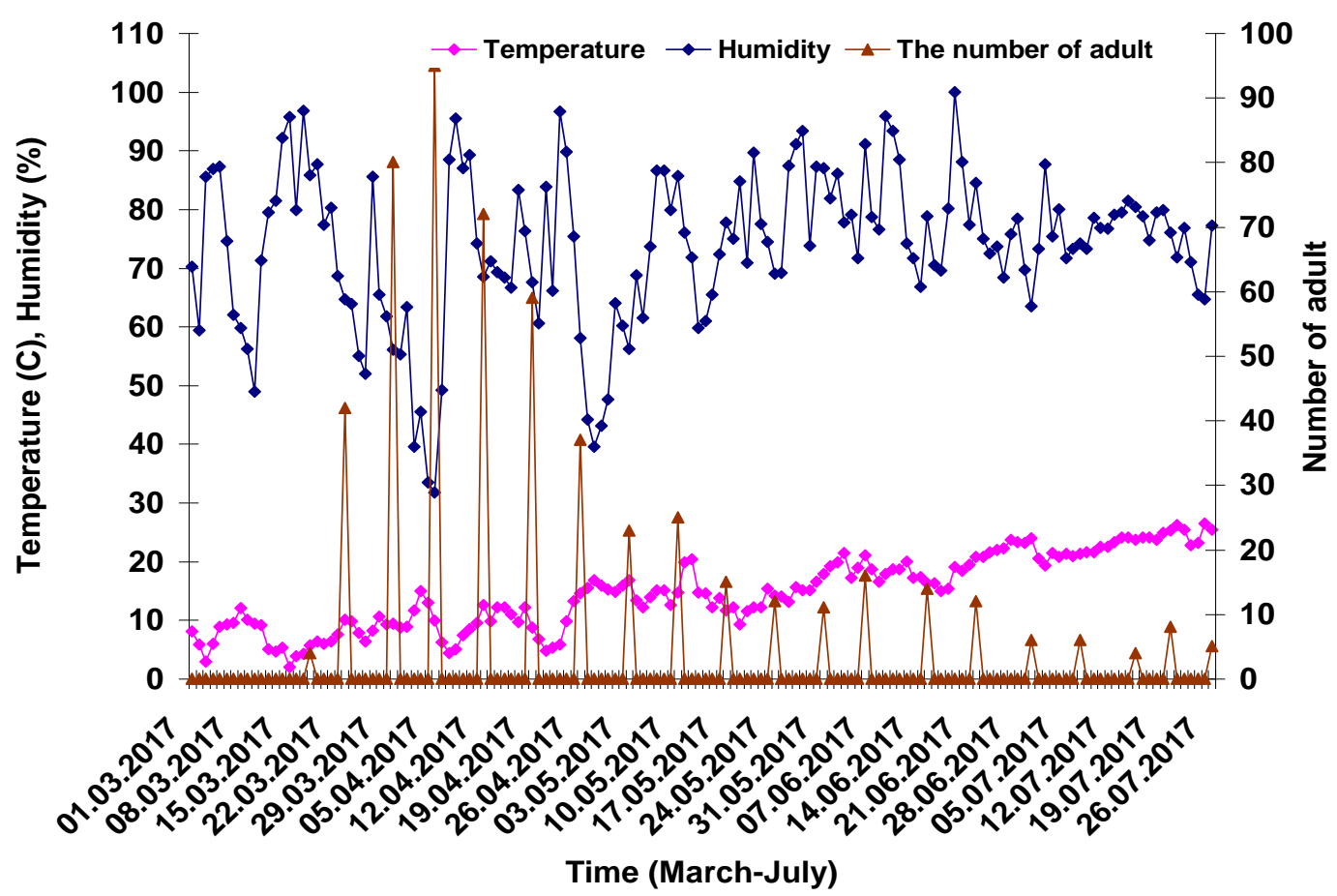

Figure 4-Temperature, humidity and the number of adults obtained from in the spring planting garlic

Furthermore, in the spring planting, the highest number of adults were 95 adults/week/trap on April 5, 2017. The average temperature and humidity were $10^{\circ} \mathrm{C}$ and $32 \%$, respectively (Figure 5).

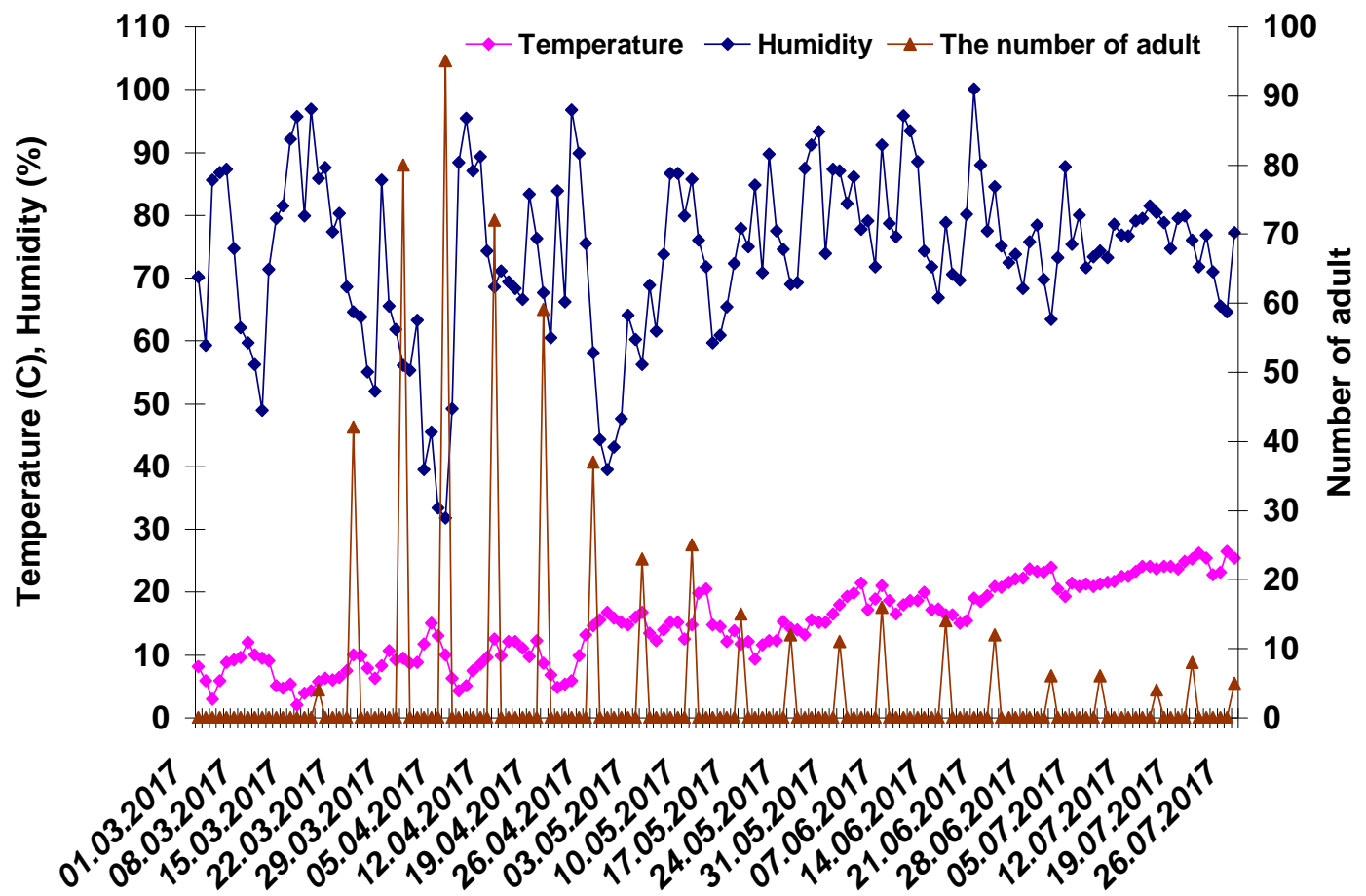

Time (March-July)

Figure 5-Temperature, humidity and the number of adults obtained from in the autumn planting garlic 
These findings are consistent with those of following studies. For example, Broatch \& Vernon (1997) carried out population monitoring of $D$. platura by using yellow sticky trap, and they reported that the adults of $D$. platura emergence was on the beginning of March. The authors also reported that the population density was very high in April and May, then the emergence continued until the end of the harvest even in the low population, and the average temperature was $22{ }^{\circ} \mathrm{C}$ in the periods when the population of $D$. platura was very high. Similarly, in our study, the average temperature during the trial was $23^{\circ} \mathrm{C}$. Moreover, adults are very numerous in the spring (two to three generations), but their population starts decreasing substantially in mid-summer (Eckenrode et al 1973; Hagel et al 1981; Sanborn 1981).

The most important harmful species in the study of garlic fields in our study was the $D$. platura, which were spread over the entire area, and the rate of harmful infestation increased to $41 \%$ in some areas. Related literature have reported similar findings. For example, Bessin (2004) reported $D$. platura damaging newly planted seeds by feeding on seed contents, often-leaving empty seed shells and preventing germination. Germinate seeds that due to damage are spindly with few leaves and die before maturation. $D$. platura induced damage is facilitated by early planting dates, heavy cover crops, and cool-wet weather (Bessin 2004). Occasionally, D. platura tunnel within seedling stems and germinating seeds (Funderburk et al 1983). Usually no more than $2 \%$ of the seedlings get infested by this insect yet $30 \%$ to $60 \%$ plant loss may occur in the field. Reduction in the plant stand can be seen within a week after plant emergence (Gesell 2000).

\section{Conclusions}

The adults of the insect was recognized as D. platura, which was first observed in Turkey in this study carried out in garlic area, and the population monitoring of D. platura was determined. In the population monitoring study were determined that that the first adult emerged on March both in the autumn planting and the spring planting (Average temperature and humidity $10{ }^{\circ} \mathrm{C}$ and $65 \%$ respectively), and the adult population increased until the beginning of March, April and May and then it decreased. In addition, it was revealed that the amount of precipitation negatively affected the adult population of $D$. platura.

\section{Acknowledgements}

This work was funded by Republic of Turkey, Ministry of Agriculture and Forestry, General Directorate of Agricultural Research and Policies of the Project with the number TAGEM-BS-12/09-07/01-14

\section{References}

Anonymous (2008). Tarım ve Orman Bakanlı̆̆ı, Tarımsal Araştırmalar Genel Müdürlüğü, Zirai Mücadele Teknik Talimatı, Ankara Cilt 3. 306-308

Anonymous (2015). https://www.google.com.tr/searchq.meteolroloji.genel.müdürlüğü\&rlz

Anonymous (2016). https://www.2.gov.bc.ca/phu-garlic-insect-pests.pdf

Anonymous (2017). https://www.google.com.tr/searchq.meteolroloji.genel.müdürlüğü\&rlz

Anonymous (2018a). https://www.webmd.com/vitamins/ai/ingredientmono-300/garlic

Anonymous (2018b). www.tuik.gov.tr.

Bessin R (2004). Corn: Cool soils favor damage by some insect pests. Kentucky Pest News. Number 985

Broatch J S \& Vernon R S (1997). Comparison of water pan traps and sticky traps for monitoring Delia spp. (Diptera: Anthomyiidae) in canola. The Canadian Entomologist 129: 979-984

Eckenrode C J, Gauthier N L, Danielson D \& Webb D R (1973). "Seedcorn maggot: seed treatments and granule furrow applications for protecting beans and sweet corn”. Journal of Economic Entomology 66: 1191-1194

Ellis S A \& Scatcherd J E (2007). Bean seed fly (Delia platura, Delia florilega) and onion fly (Delia antiqua) incidence in England and an evaluation of chemical and biological control options. Annals of Applied Biology 151(2): 259-267

Erdoğan P, Barış A \& Alpkent Y N (2014). Orta Anadolu Bölgesinde domateslerde zararlı olan Domates güvesi [Tuta absoluta Meyrick (Lep.: Gelechiidae)]'nin ve doğal düşmanlarının sürveyi ile popülasyon takibi. Bitki Koruma Bülteni 54(3): 255-265 
Robert S, Vernon G J R, Judd J \& Borden H (1987). Commercial monitoring programme for the onion fly, Delia antiqua (Meigen) (Diptera: Anthomyiidae) in south-western British Columbia, Crop protection 6(5): 304-312

Funderburk J E, Pedigo L P \& Berry E C (1983). Seedcorn maggot (Diptera: Anthomyiidae) emergence in conventional and reducedtillage soybean systems in Iowa. Journal of Economic Entomology 76: 131-134

Gesell S (2000). Seed corn maggot as a pest of field corn. Entomological notes, Department of Entomology, Penn State University

Griffiths G C D (1986) Relative abundance of the root maggots Delia radicum (L.) and D. floralis (Fallen) (Diptera: Anthomyiidae) as pests of canola in Alberta. Quaestiones Entomologicae 22: 253-260

Griffiths G C D (1993). Anthomyiidae. In: Flies of the Nearctic Region, 8 (2), 10. Edited by G.C.D. Grifths. E. Schweizerbart, Stuttgart, Germany. pp. 1417-163

Hagel G T, Burke D W \& Silbernagel M J (1981). "Response of dry bean selections to field infestations of seedcorn maggot in central Washington". Journal of Economic Entomology 74: 441-443

Has A, Dörtbudak N, Çalışkaner S, Aydemir M \& Erdoğan P (1996). Patates güvesi Phthorimae operculella Zeller'in Tarla ve laboratuvar koşullarında Biyolojisi. II. Ulusal Patates Kongresi 28-30 Haziran 1999, Erzurum, pp. 202-215

Howard R J, Garland J A \& Seaman W L (1994). Disease and Pests of vegetable Crops in Canada. An Illustrated compendium. The Canadian Phytopathological Society and The Entomological Society of Canada, Ottawa, Canada

Kansu İ A (2005). Böcek Çevre Bilimi (Böcek Ekolojisi). Ankara Üniversitesi Ziraat Fakültesi Yayınları, No: 1045 Ders Kitabı: 302

Kessing J L M \& Mau R F L (1991). Seed corn maggot, Delia platura (Meigen). Crop Knowledge Master. Department of Entomology, Honolulu, Hawaii (Unpublished)

Kornegay J \& Cardona C (1991). Breeding for insect resistance in beans. In: van Schoonhoven A. Voysest O. (Eds.), Common Beans: Research for Crop Improvement. CAB International/ CIAT, Wallingford, California, pp. 619-648

Raman K V, Booth R H \& Palacios M (1987) Control of potato tuber moth Phthorimaea oprrculella (Zeller) in rustic potato stores. Tropical Science, 27: 568-569

Ristich S S (1950). Biology of seed-corn maggot, Hylemya cilicrura (Rondani), and preliminary studies on its control. Ph.D. dissertation, Cornell University, Ithaca, New York

Sanborn S M (1981). European corn borer management on snap beans; seedcorn maggot in relation to snap bean root rot; and seedcorn maggot development in relation to temperature. Unpublished Ph. D. dissertation, University of Wisconsin, Madison. $124 \mathrm{pp}$

Trotus E, Ghizdavu I \& Malschi D (1996). "Structura speciilor de muste din genul Delia, daunatoare culturilor de fasole". Problems Protection Plant 24: 35-39

Vernon R S, Hall J W, Judd G R R \& Bartel D L (1987). Improved Monitoring Program for Delia antiqua (Diptera: Anthomyiidae), Journal of Economic Entomology 82(1): 251-258

Von Arx R, Goueder J \& Temime A B (1987). Integrated control of potato tubermoth Phthorimae operculella (Zeller) in Tunusia. Insect Science and Application 8: 989-994

Zümreoğlu S (1996). Tütün gebesi [Phthorimae operculella (Zeller) (Lepidoptera: Gelechiidae)] biyolojisi ve zararı üzerinde araştırmalar. Türkiye 1. Entomoloji Derneği Yayınları, No: 3, İzmir, pp. 149-156 